\title{
Voluntary carbon credits from improved forest management: policy guidelines and case study
}

\author{
Giorgio Vacchiano (1), \\ Roberta Berretti (2), \\ Raoul Romano (2), \\ Renzo Motta ${ }^{(1)}$
}

\begin{abstract}
Human activities have the potential to enhance carbon sequestration by the world's forests and contribute to climate change mitigation. Voluntary carbon trading is currently the only option to pursue and reward carbon sequestration by forestry activities. Carbon credits for enhanced sequestration can be sold to partners wishing to offset their own emissions. Here we illustrate the steps taken to design guidelines for the generation of voluntary carbon credits by improved forest management in Piemonte, Italy. The guidelines have been developed in a joint effort by academia, regional administrations, forest owners and professional consultants. In particular, we show how to compute the baseline and the additionality of credit-generating forest management activities, and how to reconcile the generation of forest carbon credits with law requirements, technical limitations, and the provision of other ecosystem services. To illustrate the profitability of carbon credit generation, we simulated the application of carbon credit guidelines to two forest-rich mountain watersheds in the southern part of the Piemonte region. The two dominating tree species are beech (Fagus sylvatica L.) and chestnut (Castanea sativa Mill.). We computed current forest carbon stock and carbon credits generated in 20 years under business as usual and an alternative biomass retention scenario. The IFM resulted in an avoided harvest of $39,362 \mathrm{~m}^{3}$ for a net total of 64,014 $\mathrm{MgCO}_{2} \mathrm{e}$ after subtracting harvest emissions, or $38 \mathrm{Mg} \mathrm{ha}^{-1}$ throughout the permanence period of 20 years. These steps can be replicated in other mountain regions where there is interest in promoting this ecosystem service as an alternative or an addition to production-oriented forest management.
\end{abstract}

Keywords: Carbon Stocks, Carbon Credits, Biomass, Coppice, Ecosystem Services, Forest Management Plan, Climate Change Mitigation, Retention Forestry

mate change mitigation mandate or recommend specific actions to increase forest sinks that apply to all member states or subscribing partners, e.g., the United $\mathrm{Na}$ tions Framework Convention on Climate Change (UNFCCC), the Kyoto Protocol $(K P)$, the Doha Amendment to the KP (2012-2020), the series of decisions by the Conference of the UNFCCC Parties (COP), the United Nations Programme on Reducing Emissions from Deforestation and Forest Degradation (REDD), the California Carbon Allowances (CCA) in the United States. Among the major existing climate mitiga-
(1) Università degli Studi di Torino, Dipartimento di Scienze Agrarie, Forestali e Alimentari, Largo Braccini 2, I-10095 Grugliasco, TO (Italy); (2) Consiglio per la Ricerca in agricoltura e l'analisi dell'Economia Agraria (CREA), Centro di ricerca Politiche e Bioeconomia, v. Po 14 , I-00198 Roma (Italy)

@ Giorgio Vacchiano (gvacchiano@gmail.com)

Received: Mar 15, 2017 - Accepted: Oct 17, 2017

Citation: Vacchiano G, Berretti R, Romano R, Motta R (2018). Voluntary carbon credits from improved forest management: policy guidelines and case study. iForest 11: 1-10. - doi: 10.3832/ifor2431-010 [online 2018-01-09]

Communicated by: Marco Borghetti tion programs, forestry is conspicuously absent only from the European Union Emission Trading Scheme (EU-ETS), the world's largest cap-and-trade scheme.

In cap-and-trade schemes such as KP or CCA, pre-compliance carbon "credits" can be generated from activities that reduce $\mathrm{CO}_{2}$ emission or enhance carbon sequestration. Credits for reduced emissions or enhanced sequestration can be sold to partners wishing to offset their own emissions and to avoid topping the mandatory emission caps (Low \& Lin 2015). One offset credit corresponds to an emission reduction of $1 \mathrm{Mg}$ of $\mathrm{CO}_{2}$ equivalent.

On top or in the absence of binding government agreements ("compliance markets"), individual entities can commit to generate additional voluntary credits and sell them on a free ("over the counter") or regulated market, e.g., the InterContinental Exchange (formerly the Chicago Climate Exchange). Such voluntary market of carbon credits (Bayon et al. 2007) has grown to a cumulated volume of $990 \mathrm{Tg} \mathrm{CO}_{2} \mathrm{e}$ in emission reductions, worth US\$ 4.6 billion as of 2015 (Hamrick \& Goldstein 2016).

In Europe, the EU-ETS is the main driver of the international carbon market and the main provider of clean energy investment in developing countries and economies in 


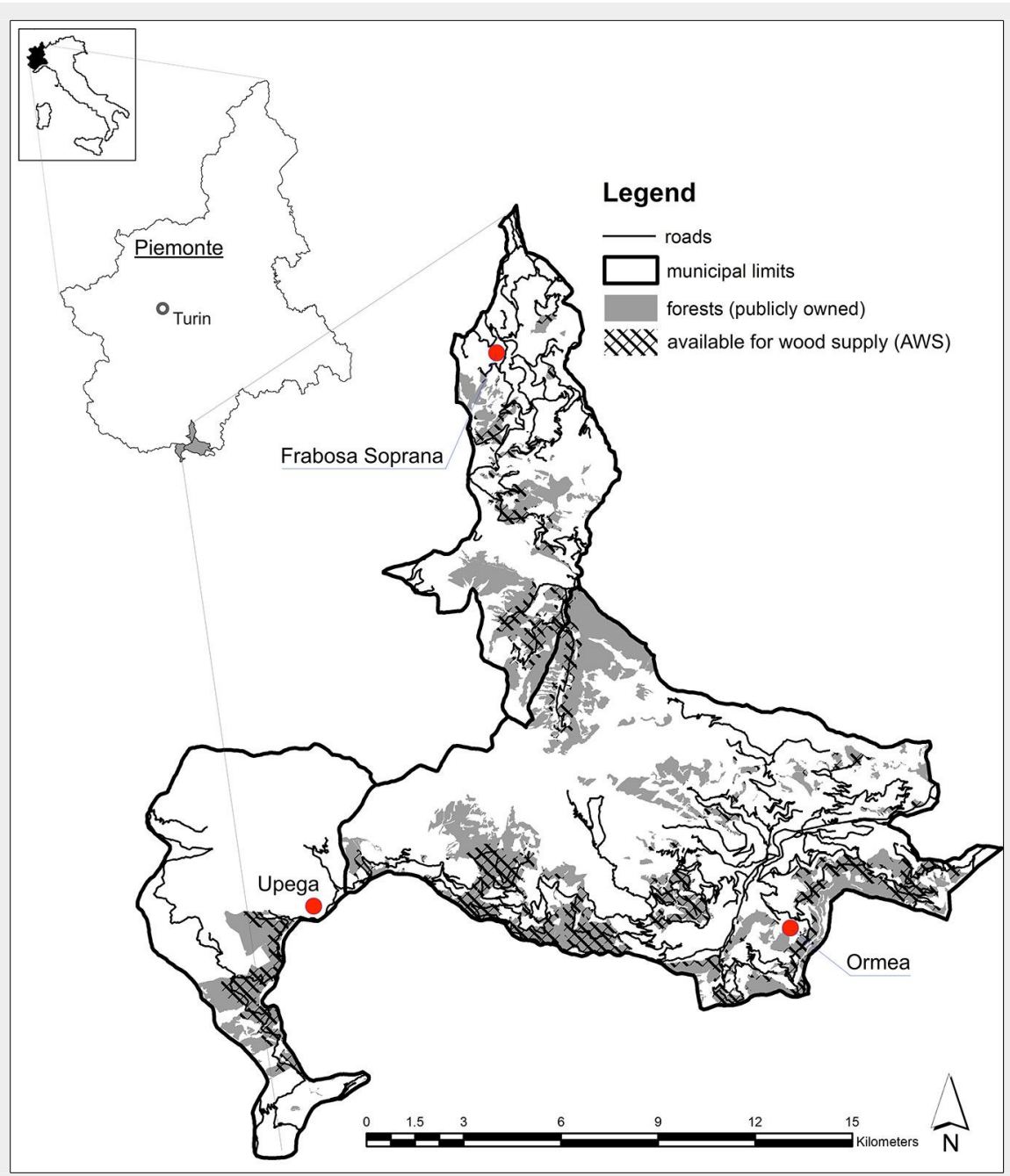

Fig. 1 - Case study area.

transition. However, following the expiration of the first commitment period of the $\mathrm{KP}$, the exclusion of forest sinks from EUETS, and the uncertainty that still surrounds the implementation of the Paris Agreement, voluntary carbon trading is now the only option to pursue and reward carbon sequestration by forestry activities. Currently, such activities are free from the problem of "double accounting", i.e., enlisting carbon credits under both the voluntary and the compliance carbon markets, at least where no other governmental binding cap-and-trade or carbon tax is in place.

In its national commitments to the Kyoto Protocol, Italy included $10 \mathrm{MgCO}_{2} \mathrm{e} \mathrm{ha}{ }^{-1}$ year-1 from carbon sequestration by forestry activities, in public and private forests, out of a total of $50 \mathrm{MgCO}_{2} \mathrm{e} \mathrm{ha}^{-1}$ year $^{-1}$ absorbed by Italian forests (Tomao et al. 2013) - a commitment that will be possibly ramped up to comply with the Intended Nationally Determined Contribution of the $\mathrm{EU}$ to the Paris Agreement (INDC). The value of this ecosystem services can be considered equal to the sum of all avoided mitigation costs by other industrial sectors; however, none of this money was returned as compensation or investment in the for- estry sector (Alisciani et al. 2011). Local voluntary carbon credits markets have the potential to compensate forest owners for this unequal appropriation of resources, and as an option to diversify revenue and support sustainable management.

Three types of forestry activities may generate carbon credits: (a) afforestation on non-forested lands or reforestation, where carbon is sequestered and offsets are generated through the creation or reestablishment of forest land use; (b) avoiding emissions from deforestation and degradation, i.e., retaining forest as forest; and (c) improved forest management (IFM), i.e., forest management that increases the carbon stocked in the forest (by better logging practices, longer rotation, or other means) and/or in wood products (by producing more durable assortments), relative to business as usual. IFM credits are the most promising for the regional forestry sector, because they can provide income to public and private forest owners, and increase the economic interest in carrying out sustainable forest management activities. Methodologies to facilitate the definition and transfer of carbon credits generated by IFM (chiefly by carbon stock enhancement) are of great interest worldwide, both in developed and developing countries, within the climate change mitigation framework. However, because voluntary carbon markets have an international size, credits can be purchased from sites far away from where the offset will eventually occur. A way to attain the simultaneous benefits of climate mitigation and promoting the forestry sector and jobs is to establish local voluntary carbon markets, i.e., where credits can be sold by forestry activities carried out within a given region (Ciccarese et al. 2011).

This paper develops a set of guidelines that might be applied as a way for the generation of carbon credits for the voluntary market from IFM in the Piemonte region (northern Italy). Such guidelines were established by the regional administration in 2015-2017, and referenced in the new Regional Forest Plan (Regione Piemonte 2017), with the aims of: (a) suggesting forest management schedules that qualify for the generation of $C$ credits; (b) suggesting the minimum content of Project Design Documents, i.e., the documentation that quantifies carbon benefits of the project using rigorous methodological approaches, to be independently validated, and later verified for issuance of certified carbon credits (Olander \& Ebeling 2011); (c) mandating a regional register of $C$ credits from forestry activities. National guidelines for voluntary carbon credits already existed in Italy (Nucleo Monitoraggio Carbonio 2014). These indicate which certification standards must be complied with, e.g., ISO 14064-2 (Weng \& Boehmer 2006), the Verified Carbon Standard (VCS), or the Gold Standard (Green 2013), require a given temporal permanence of carbon sequestration activities (20 years), and fix the entity of buffering for unplanned natural disturbances and leakage, i.e., loss of carbon due to compensatory intensification of land use outside the area of the project.

Methods for carbon accounting in forests are well-established (Vitullo et al. 2007). Currently, most scientific studies on the impact of alternative forest management on carbon stocked by the forest rely on explicit modeling of forest or ecosystem dynamics (Chen et al. 2000, Masera et al. 2003, Lasch et al. 2005, Bravo et al. 2008, Swanson 2009). However, empirical or process-based forest dynamics models calibrated to Italian forests are still lacking (Vacchiano et al. 2012). Therefore, we opted herein for a simpler approach based on differences in aboveground carbon stocks resulting from the management alternatives being compared at the end of the carbon project validity period.

Moreover, one of the most important requirements for carbon projects is additionality, i.e., greenhouse gas removals must be greater after the implementation of the project than those resulting from a "baseline" scenario (McFarland 2012). The methodological approach presented here focuses on the definition of a baseline to de- 
monstrate additionality in carbon credits that are generated. Application of the guidelines will be demonstrated by running a full analysis of potential $C$ credits from improved forest management in a mountain watershed dominated by broadleaves as a case study. Although local, the framework used for the definition of applicable guidelines and the practical steps for their implementation can be seamlessly adopted in other regions or countries.

\section{Material and methods}

\section{Study area}

The forestry sector currently accounts for only $0.3 \%$ of the regional GDP (Schulz et al. 2014). The pilot carbon credit assessment was carried out in three municipalities of Alta Valle Tanaro and Val Maudania, two mountain watersheds in southern Piemonte (Fig. 1). The study area has a total area of 22,059 ha, of which 11,548 ha are forested. Forests are dominated by beech ( $\mathrm{Fa}$ gus sylvatica L.) and chestnut (Castanea sativa Mill.) coppices ( $28 \%$ of total forest cover each), the two most widespread tree species in the Piemonte region (NW Italy) (Tab. 1). Forest ownership is $43 \%$ public (municipalities) and $57 \%$ private. Protected areas cover 5,035 ha (Regione Piemonte 2016a) of which 1,774 covered by forests; another 5,305 ha is classified as direct protection forests (IPLA, unpublished data).

\section{Eligible activities for improved forest management}

The requirement of additionality means that eligible IFM activities may include lengthening rotations, increasing minimum harvestable tree size, improving forest or soil productivity, or giving up part of the woody increment that would be harvested by ordinary forest management.

To promote a sustainable and proactive silviculture, the regional guidelines (Regione Piemonte 2017) set two preliminary requirements for the eligibility of $C$ credits: (i) that a forest management plan exists or is designed; and (ii) that active management is carried out, i.e., silvicultural abandonment is discouraged.

On top of these, additionality can be assessed relative to one or more of several possible baselines, including law requirements (legal additionality), common practice in the sector and region (technical additionality), and whether the project would have been financially attractive without the revenue from carbon reduction credits (financial additionality - McFarland 2012). Disregarding the latter, which presents issues of subjectivity and confidentiality, and is being phased out by many international standards, the problem rests on how to determine legal and technical additionality, and whether they might coincide (Fig. 2).

\section{Legal baseline and its units of} measurements

The first way to define a baseline is by re-
Tab. 1 - Forest cover types of Piemonte, Italy (source: Gottero et al. 2007) and species codes used in this study.

\begin{tabular}{|c|c|c|}
\hline Forest cover type & code & Area (ha) \\
\hline Chestnut (Castanea sativa Mill.) & casa & 204,368 \\
\hline Beech (Fagus sylvatica L.) & fasy & 135,770 \\
\hline Deciduous oaks and hop-hornbeam (Ostrya carpinifolia Scop.) & qupe & 133,244 \\
\hline Black locust (Robinia pseudoacacia L.) & rops & 108,136 \\
\hline Secondary woodlands (birch, hazelnut, aspen) & wood & 100,779 \\
\hline Larch (Larix decidua Mill.) & lade & 79,536 \\
\hline $\begin{array}{l}\text { Scots pine (Pinus sylvestris L.) and mountain pine } \\
(P . \text { uncinata Mill.) }\end{array}$ & pisy & 36,789 \\
\hline Shrubland & shru & 34,317 \\
\hline $\begin{array}{l}\text { Spruce (Picea abies (L.) Karst.) and } \\
\text { fir (Abies alba Mill.) }\end{array}$ & $\begin{array}{l}\text { piab, } \\
\text { abal }\end{array}$ & 24,046 \\
\hline $\begin{array}{l}\text { Riparian and moist woodlands } \\
\text { (alder, willow, poplar, maple-ash) }\end{array}$ & ripa & 17,675 \\
\hline
\end{tabular}

ferring to the maximum allowable cut for actively managed forests in the study area, as defined by extant law restrictions. These are the Forest Management Act (FMA - Regione Piemonte 2011) or, for protected areas, by the Best Conservation Practices for Natura 2000 areas (Regione Piemonte 2014). Such regulatory frameworks provide minimum retention requirements for each type of silvicultural entry and forest cover type, expressed in units of percent canopy cover retained after harvest (Tab. 2). This unit of measurement is ecologically meaningful (Lowman \& Rinker 2004), but had to be transformed into units of biomass, such as basal area or volume, to be used for carbon estimation.

Even between units of measurements with the same allometric properties, such as basal area and crown projection area (both scaling with the second power of stem diameter), the relationship at the stand level is highly variable, due to crown plasticity, site index, differences in tree dominance, and species-specific leaf and crown architecture traits (Mitchell \& Popo- vich 1997). However, we hypothesized that a robust cross-species relationship could exist when those variables are expressed in relative terms, i.e., between retained canopy cover $R$ and relative harvested volume $V_{\mathrm{h}}$. As new could find no template for such relationship in the available literature, we suggest a fully parameterized negativeexponential relationship expressed as follows (eqn. 1):

$$
V_{h}=a\left(b-e^{c R}\right)
$$

derived from the assumption that the harvest rate calculated on volume is logarithmically proportional to canopy removed (eqn. 2):

$$
\ln V_{h} \propto 1-R
$$

where $R$ and $V_{h}$ are both constrained between 0 and $100 \%$. If validated, such relationship would allow us to convert all provisions from FMA into maximum percent volume that can legally be removed at each silvicultural entry from any forest. To

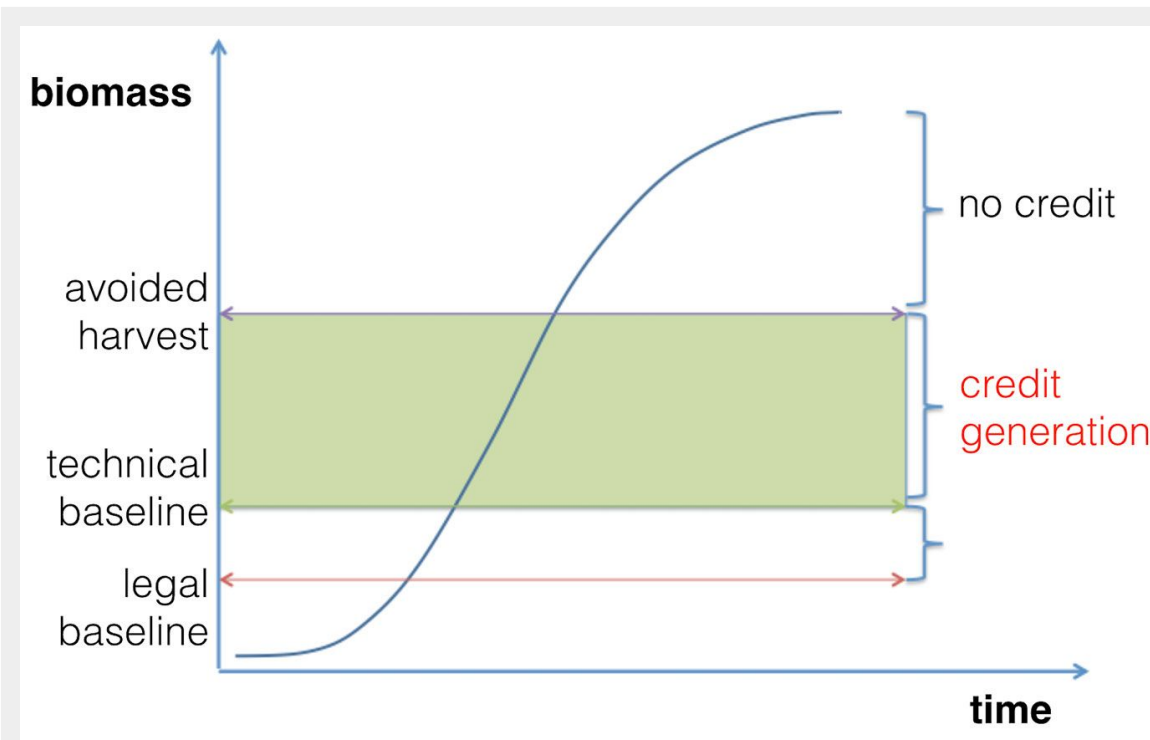

Fig. 2 - Baselines and additionality for the generation of Carbon credits from IFM. 
Tab. 2 - Minimum post-harvest canopy cover or volume to be retained after harvest for each management type according to the regional Forest Management Act (Regione Piemonte 2011), legal and technical baseline. (a): Shelterwood does not generate carbon credits because it relies on the complete removal of the overstory. Moreover, no cases were available to define the technical base line. (b): Thinning from below does not generate carbon credits because harvest rates lower than the technical baseline are not recommended under an economic and ecological point of view.

\begin{tabular}{|c|c|c|c|c|}
\hline Management class & $\begin{array}{c}\text { FMA prescription } \\
\text { (minimum canopy cover } \\
\text { post-harvest) }\end{array}$ & $\begin{array}{l}\text { Legal baseline } \\
\text { (maximum volume } \\
\text { removed) }\end{array}$ & $\begin{array}{c}\text { Technical baseline } \\
\text { (maximum volume } \\
\text { removed) }\end{array}$ & $\begin{array}{l}\text { IFM in the pilot } \\
\text { area (volume } \\
\text { removed) }\end{array}$ \\
\hline Coppice, age $<40$ years & $\begin{array}{l}>10 \% \text { cover, } \\
>20 \% \text { in beech forests }\end{array}$ & $\begin{array}{l}84 \% \text { in beech } \\
90 \% \text { in other }\end{array}$ & $\begin{array}{l}83 \% \text { in beech } \\
90 \% \text { in other }\end{array}$ & - \\
\hline $\begin{array}{l}\text { Coppice, age }<40 \text { years, conversion to high } \\
\text { forest }\end{array}$ & $>50 \%$ cover & $55 \%$ & $50 \%$ & $40 \%$ \\
\hline $\begin{array}{l}\text { Coppice, age }>40 \text { years, conversion to high } \\
\text { forest }\end{array}$ & $>50 \%$ cover & $60 \%$ & $50 \%$ & $40 \%$ \\
\hline Mixed coppice and high forest & $>40 \%$ cover & $60 \%$ & $50 \%$ & - \\
\hline $\begin{array}{l}\text { Mixed coppice and high forest, conversion to } \\
\text { high forest }\end{array}$ & $>50 \%$ cover & $55 \%$ & $50 \%$ & - \\
\hline High forest, even-aged, shelterwood & $\begin{array}{l}>80-120 \mathrm{~m}^{3} \mathrm{ha}^{-1} \text {, according } \\
\text { to dominant species }\end{array}$ & - (a) & - (a) & - \\
\hline High forest, gap cut & $>70 \%$ cover & $40 \%$ & $40 \%$ & $30 \%$ \\
\hline High forest, even-aged, thinning & $>50 \%$ cover & $66 \%$ & $\begin{array}{l}35 \% \text { from above } \\
20 \% \text { from below }^{(b)}\end{array}$ & $30 \%$ \\
\hline $\begin{array}{l}\text { High forest, uneven-aged, single tree } \\
\text { selection }\end{array}$ & $>90 \mathrm{~m}^{3} \mathrm{ha}^{-1}$ & $70 \%$ & $\begin{array}{l}35 \% \text { in conifers } \\
40 \% \text { in broadleaves }\end{array}$ & - \\
\hline $\begin{array}{l}\text { Black locust, regeneration cut (except } \\
\text { conversion of coppice to high forest) }\end{array}$ & Leave all native species & $90 \%$ & $\begin{array}{l}87 \% \text { if monospecific } \\
55 \% \text { if mixed }\end{array}$ & $70 \%$ \\
\hline $\begin{array}{l}\text { Chestnut, regeneration cut (except } \\
\text { conversion of coppice to high forest) }\end{array}$ & $\begin{array}{l}>30 \% \text { cover by other native } \\
\text { species If monospecific, } \\
>10 \% \text { cover by chestnut }\end{array}$ & $90 \%$ & $\begin{array}{l}90 \% \text { if monospecific } \\
65 \% \text { if mixed }\end{array}$ & $70 \%$ \\
\hline
\end{tabular}

calculate the baseline for a wide variety of eqn. 1 by simulating silvicultural treatments of conifers and broadleaves in the region, forest cover types and harvest regimes, in 12 intensively measured forest plots with and ranged in size between 0.27 and 1 ha and due to a lack of long-term monitoring different species composition and struc- (Tab. 3). In each plot and for all living trees, plots where the temporal dynamics of ca- ture. Plots were chosen in pure or nearly we measured tree species, diameter at 130 nopy cover were measured, we calibrated pure stands dominated by the main species $\mathrm{cm}$ height (dbh, diameter at breast height),

Tab. 3 - Description of case studies for the computation of the legal baseline (low/high intensity harvest).

\begin{tabular}{|c|c|c|c|c|c|c|c|c|c|}
\hline Plot ID & $\begin{array}{l}\text { Dominant } \\
\text { species }\end{array}$ & $\begin{array}{l}\text { Elevation } \\
\text { (m a.s.l.) }\end{array}$ & $\begin{array}{c}\text { Area } \\
\text { (ha) }\end{array}$ & $\begin{array}{l}\text { Stand } \\
\text { structure }\end{array}$ & Treatment & $\begin{array}{l}\text { Trees } \\
\text { ha }^{-1}\end{array}$ & $\begin{array}{l}\text { Volume } \\
\left(\mathrm{m}^{3} \mathrm{ha}^{-1}\right)\end{array}$ & $\begin{array}{c}\text { Trees } \\
\text { removed } \\
(\%)\end{array}$ & $\begin{array}{c}\text { Volume } \\
\text { removed } \\
\text { (\%) }\end{array}$ \\
\hline Pragelato & lade & 1,450 & 0.49 & $\begin{array}{l}\text { High forest, } \\
\text { even-aged }\end{array}$ & Thinning & 674 & 485 & $37 / 63$ & $34 / 59$ \\
\hline Saint-Rhémy & lade & 1,800 & 0.27 & $\begin{array}{l}\text { High forest, } \\
\text { even-aged }\end{array}$ & Thinning & 574 & 474 & $41 / 68$ & $36 / 65$ \\
\hline Acceglio & abal & 1,400 & 0.52 & $\begin{array}{l}\text { High forest, } \\
\text { uneven-aged }\end{array}$ & $\begin{array}{l}\text { Single tree } \\
\text { selection }\end{array}$ & 1,003 & 567 & $39 / 80$ & $35 / 81$ \\
\hline Chiusa Pesio & abal & 1,150 & 1.00 & $\begin{array}{l}\text { High forest, } \\
\text { uneven-aged }\end{array}$ & $\begin{array}{l}\text { Single tree } \\
\text { selection }\end{array}$ & 701 & 713 & $19 / 68$ & $32 / 82$ \\
\hline Fenestrelle & pisy & 1,650 & 0.51 & $\begin{array}{l}\text { High forest, } \\
\text { even-aged }\end{array}$ & Thinning & 528 & 651 & $25 / 46$ & $39 / 69$ \\
\hline Morgex & pisy & 1,091 & 0.60 & $\begin{array}{l}\text { High forest, } \\
\text { even-aged }\end{array}$ & Thinning & 713 & 239 & $33 / 62$ & $33 / 71$ \\
\hline S. Maria & pisy & 1,050 & 0.60 & $\begin{array}{l}\text { High forest, } \\
\text { even-aged }\end{array}$ & Shelterwood & 768 & 279 & $46 / 76$ & $42 / 71$ \\
\hline Trasquera & pisy & 1,247 & 0.64 & $\begin{array}{l}\text { High forest, } \\
\text { uneven-aged }\end{array}$ & $\begin{array}{l}\text { Group } \\
\text { selection }\end{array}$ & 315 & 243 & $19 / 43$ & $30 / 55$ \\
\hline Chialamberto 1 & casa, qupe & 1,000 & 0.56 & Coppice & $\begin{array}{l}\text { Conversion to } \\
\text { high forest }\end{array}$ & 1,144 & 298 & $29 / 65$ & $22 / 63$ \\
\hline Chialamberto 2 & casa, qupe & 1,001 & 0.56 & $\begin{array}{l}\text { High forest, } \\
\text { even-aged }\end{array}$ & Shelterwood & 1,144 & 298 & $65 / 79$ & $42 / 60$ \\
\hline Ala di Stura & fasy & 1,350 & 0.84 & $\begin{array}{l}\text { High forest, } \\
\text { even-aged }\end{array}$ & Thinning & 778 & 284 & $42 / 72$ & $30 / 67$ \\
\hline Vernante & fasy & 1,600 & 0.65 & $\begin{array}{l}\text { High forest, } \\
\text { even-aged }\end{array}$ & Thinning & 908 & 413 & $39 / 73$ & $31 / 76$ \\
\hline Vallarsa & fasy & 1,050 & 0.84 & $\begin{array}{l}\text { High forest, } \\
\text { even-aged }\end{array}$ & Thinning & 910 & 264 & $27 / 75$ & $29 / 69$ \\
\hline
\end{tabular}


total height, crown radii in the four cardinal directions, and tree position relative to the plot origin. Individual tree crowns were delineated by bidimensional splines fitted to the four crown projection endpoints, and total canopy cover was computed as the fraction of plot covered by projected crowns (without overlap). Total tree volume was computed by means of local and national volume equations (Nosenzo 2005, 2008, Tabacchi et al. 2012). For each plot, we simulated a silvicultural treatment compatible with species traits and forest structure (i.e., thinning in early-seral even-aged high forest, shelterwood in late-seral evenaged high forests, conversion to high forest in coppices, single tree selection in lateseral uneven-aged forest, group selection in early-seral uneven-aged forest). For each treatment, we simulated two harvest intensities, whereby the relative volume to be harvested (low intensity: 20-50\%, high: $50-85 \%$ ) and the number of trees to remove for each dbh class were defined on a case by case basis after consulting with local forest managers. To account for random selection of trees to remove within each dbh class, we simulated 20 iterations of each cut; once decided how many trees to remove from each dbh class, in each iteration we let a random algorithm decide which specific trees to remove from that class. For each group of 20 simulations, we computed the average post-harvest canopy cover as the cumulative area of individual crown polygons without overlap (Fig. 3), checked its compliance to FMA prescriptions (Tab. 2), and used it as a calibration point for eqn. 1 .

The model was finally validated against measurements of relative harvested volume and retained canopy cover in an independent set of six beech-dominated forests where experimental silvicultural treatments were carried out in years 2015-16 (details and plot description in Negro et al. 2017). This was the only readily available data set where canopy cover and growing stock were carefully measured with consistent methods before and after silvicultural interventions. $R^{2}$ and root mean square error (RMSE) of predicted vs. observed retained canopy cover were computed as validation metrics. Harvest simulations and model evaluation were carried out within the R statistical framework (R Core Team 2016).

\section{Technical baseline}

We defined the technical baseline starting from business-as-usual silviculture carried out in each of the management systems existing in the region. Since 2010, every forest management entry larger than 0.5 ha must be authorized by the regional administration, following a request that must include a description of the intervention and a measure of its intensity. We collected 403 requests filed in the years 20102013 and summing up to a harvest of 2373 ha $(23.1 \%$ of total harvested area in the

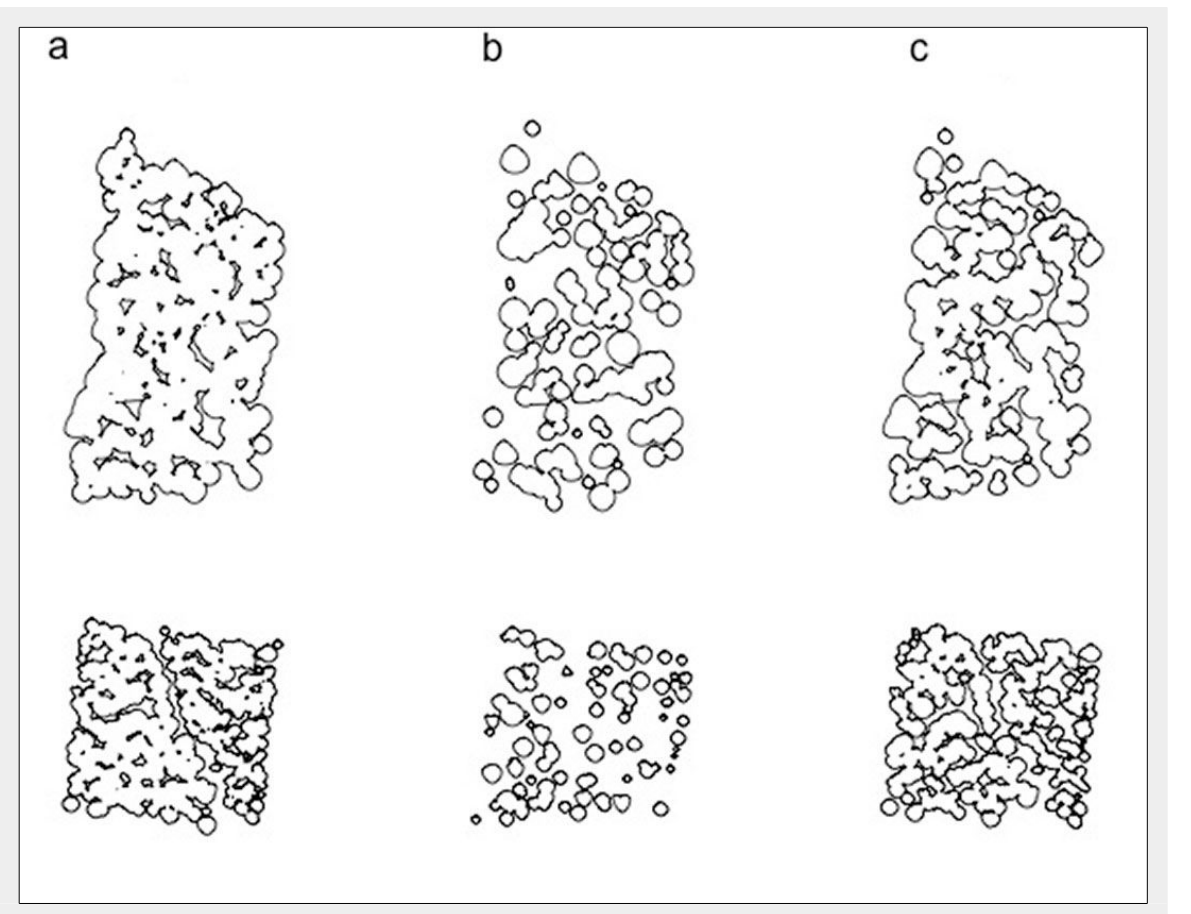

Fig. 3 - Dissolved crown polygons from an even-aged (above - plot size: 0.49 ha) and an uneven-aged forest (below - plot size: $0.51 \mathrm{ha}$ ). (a) before treatment; (b) after one random realization of the high intensity treatment; and (c) after one random realization of the low intensity treatment.

same period) in most forest cover types and by all common management types in the region (coppice, coppice conversion to high forest, thinning, and regeneration cut in high forest - Brun et al. 2014). After filtering out unclear documents (e.g., volume removed unreported, unreasonably low, or inconsistent with the management system declared), we computed the technical baseline as the average relative harvested volume for each of the management systems described by FMA (Tab. 2). The notifications covered most of the regional territory and most regional forest cover types. Forests in protected areas and forests managed for protection from natural hazards (avalanches, rockfall) were attributed a technical baseline of zero.

\section{Forest management scenarios}

In order to demonstrate the implementation of the guidelines, we computed carbon credits generated by IFM in the pilot study area, according to the following steps (Fig. 4): (i) calculate current aboveground stand volume; (ii) quantify the area available for wood supply (AWS); (iii) compute current baseline volume removals for each forest cover type and management system; (iv) define IFM schedules above the baseline for each forest management system in the area; (v) compute volume removals under IFM; and (vi) calculate differences between post-harvest growing stock (baseline minus IFM) and convert them to carbon units (Penman et al. 2003).

Current tree volume was computed using tree-level measurements recorded in all regional forest inventory plots included in the study area $(\mathrm{N}=163)$. Base grid size of the inventory was $500 \mathrm{~m}$; sample plots were circular, with a radius between 8 and $15 \mathrm{~m}$ depending on overstory density. Most plots were included in beech or larch (Larix decidua Mill.) forests (27 and $26 \%$, respectively), chestnut coppices (17\%), plantations (7\%) and secondary woodlands (birch, hazel, aspen $-7 \%$ ). In each plot, we computed the total aboveground tree volume as a function of species, dbh, and height of each tree $(\mathrm{dbh}>7.5 \mathrm{~cm})$ using national allometric equations (Tabacchi et al. 2012). To update plot volumes from the inventory year (2000-2004) to current year (2017), we added to inventory volumes the mean annual increment reported for Piemonte (range: $1.6 \mathrm{~m}^{3} \mathrm{ha}^{-1}$ year ${ }^{-1}$ for oak-hornbeam high forest to $6.1 \mathrm{~m}^{3}$ ha $^{-1}$ year ${ }^{-1}$ for chestnut coppices) by the last national forest inventory (Gasparini \& Tabacchi 2011) for each forest cover type, multiplied by the number of years occurring between the year of field survey and 2017. Plot volumes were extrapolated to the whole study area by assigning to each management unit the average volume of all plots included within its borders; management units that did not include any plot were assigned the average volume of all plots belonging to the same forest cover type across the study area.

AWS was computed by excluding all forests with harvest restrictions, i.e., private forests, areas subject by wildfire or harvest in the last 15 years (Regione Piemonte 2016b), forests classified as nonharvestable due to site or fertility limitations (Regione Piemonte 2016c), and forests inaccessible to logging equipment. Af- 


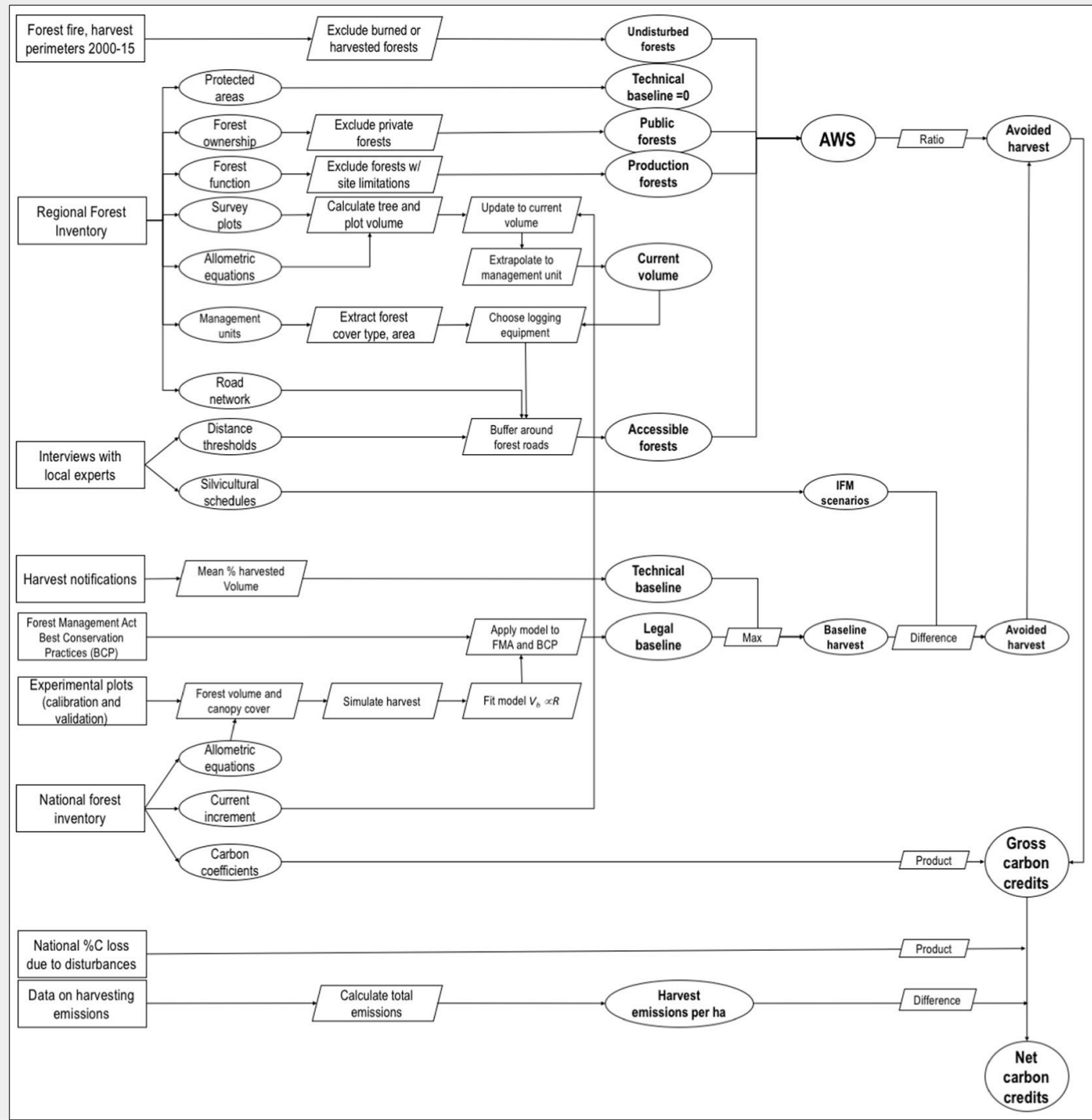

Fig. 4 - Steps followed by this study for the quantification of voluntary carbon credits from IFM (rectangles: input data, ellipses: output data, parallelograms: processes).

ter interviews with local logging enterprises, we used the following maximum distances to assess harvesting accessibility: $60 \mathrm{~m}$ upslope and $100 \mathrm{~m}$ downslope from any road for logging by tractor, $300 \mathrm{~m}$ upslope and downslope from any road for cable logging. All distances were computed using a vector map of existing public and forest roads (Regione Piemonte 2016d). The pilot area was divided into existing management units, for which area and dominant forest cover type were available from a regional forest inventory (Regione Piemonte 2016c). For each unit, the choice between tractor and cable logging was made according to the main harvestable assortment (sawlogs by cable, energy wood by tractor) and applying a minimum threshold of $100 \mathrm{~m}^{3} \mathrm{ha}^{-1}$ harvestable volume for cable logging (established by the interviewees).

Baseline harvest rates were defined using the maximum allowable rates (max of legal and technical baselines), and applied to current volume estimates. After consultation with local experts, management scenarios for the next 20 years in the pilot area were designed based on current forest structure, baseline constraints, and cri- teria of ecological and economic sustainability (Tab. 2), as follows:

- Conifer forests (mostly mature, evenaged pine and larch stands): group selection, 30\% volume removed, cable logging;

- Beech coppices: conversion to high forest (mandatory for all coppices $>40$ years old), $40 \%$ volume removed, cable logging if harvestable volume $>100 \mathrm{~m}^{3}$ ha-1, tractor logging if $<100 \mathrm{~m}^{3} \mathrm{ha}^{-1}$;

- Beech high forests: high thinning, 30\% volume removed, cable logging if harvestable volume $>100 \mathrm{~m}^{3} \mathrm{ha}^{-1}$, tractor logging if $<100 \mathrm{~m}^{3} \mathrm{ha}^{-1}$;

- Other broadleaves (mostly chestnut): coppice with standards, $70 \%$ volume removed, cable logging.

\section{Carbon accounting}

The difference in post-harvest volume between the IFM and baseline scenarios for each forest management system was scaled on a per-hectare (AWS only) and converted to tons of $\mathrm{CO}_{2}$ greenhouse gasequivalent $\left(\mathrm{MgCO}_{2} \mathrm{e}-\right.$ eqn. 3). Increment and mortality (Penman et al. 2003) were assumed to compensate each other across the permanence period and therefore not included in eqn. 3. Litter and soil carbon can contribute about half of total ecosystem carbon (Vitullo et al. 2007, Garlato et al. 2009), but were considered constant over the permanence period (20 years) and therefore left out from the calculations (eqn. 3):

$$
\begin{aligned}
\mathrm{MgCO}_{2} e & =k \sum_{i}[(1-b) \\
& \cdot\left(V_{i, I F M}-V_{i, \text { baseline }}\right) \\
& \left.\cdot B C E F_{i} \rho_{i}\left(1+R S_{i}\right) A W S_{i}\right]
\end{aligned}
$$

where $i$ are forest cover types and management systems in the pilot area, $V$ is the post-harvest volume in $\mathrm{m}^{3}$ per hectare, $\rho$ is the species-specific wood density, $R S$ is the species-specific root/shoot ratio, $B C E F$ is the species-specific biomass expansion factor (Tab. 4), $k=0.5 \cdot(44 / 12)$ is the biomassto- $\mathrm{CO}_{2}$ conversion factor, and $b$ is relative carbon lost from emissions due to unplanned natural disturbances (Murray \& Olander 2008), which we estimated at $b=9.8 \%$ over 20 years using data on carbon lost to forest fires in Italy for the period 1990-2005 (Vitullo et al. 2007). Finally, to obtain net credits we subtracted emissions due to harvesting and hauling, estimated using a fixed rate of $16 \mathrm{Kg}_{c}$ per $\mathrm{Mg}_{\mathrm{c}}$ in harvested raw material, and $7.0 \mathrm{Kg}_{c}$ per 100 
$\mathrm{km}$ of transport by truck (Van Kooten et al. 2015).

\section{Results and discussion}

\section{Baseline for eligible forest activities}

Harvest simulations for the determination of legal baselines $(\mathrm{N}=24)$ produced a good fit $\left(R^{2}=0.86\right)$ of percent volume removed as an exponential function of retained canopy cover; the parameters in eqn. 1 were $a=38.99, b=3.57, c=-0.0123$. When iterating the same treatment allowing for stochastic tree selection, retained canopy cover (mean over 20 simulations) was less variable at higher harvesting intensities and in stands dominated by shade-tolerant species, such as beech or fir. Validation of the cross-species model from eqn. 1 against independent data from beech forests produced a RMSE of 13.7 percent cover and $R^{2}=0.663$. We used such cross-species model to convert all FMA prescriptions into maximum relative volume removed, which was assumed as the legal baseline (Tab. 2). These figures were almost always higher than the technical baseline (mean percent volume removed from 180 harvest notifications, stratified by dominant species and forest management system - Tab. 2).

\section{Carbon accounting}

Mean volume across the study area was $222 \mathrm{~m}^{3} \mathrm{ha}^{-1}$. Conifer forests had the highest stocks (251 to $275 \mathrm{~m}^{3} \mathrm{ha}^{-1}$ ); broadleaves stocks ranged from $77 \mathrm{~m}^{3} \mathrm{ha}^{-1}$ (riparian woodlands) to $239 \mathrm{~m}^{3} \mathrm{ha}^{-1}$ (beech - Tab. 5).

After filtering out forests with property (6515 ha), productivity (1027), disturbance (148), and accessibility restrictions (too far from roads - 2.237), AWS was 1607 ha, i.e., $14 \%$ of total forested area (Tab. 5). This figure is significantly lower than large-scale estimates of AWS in Europe (e.g., 44-96\% in Alberdi et al. 2016), mostly due to the high incidence of protected areas, privately owned forests - particularly in chestnut (98\%) and oak (72\%) forests, and high distance from roads, mostly in pine (94\%) and larch $(60 \%)$ forests. It is not unlikely that both private owners and protected areas could be included in a forest carbon management project, if obstacles posed by property fragmentation and by allowed harvest in protected areas could be overcome.

Baseline harvest in AWS averaged $102 \mathrm{~m}^{3}$ $\mathrm{ha}^{-1}$ ( $46 \%$ of the growing stock) while IFM harvest averaged $78 \mathrm{~m}^{3}$ ha $^{-1}(35 \%)$. Application of IFM resulted in an avoided harvest of $39,362 \mathrm{~m}^{3}$, of which beech forests had the greatest share (Tab. 6), for a net total of $64,014 \mathrm{MgCO}_{2} \mathrm{e}$ after subtracting harvest emissions, or $1.99 \mathrm{MgCO}_{2}$ e ha ${ }^{-1}$ year ${ }^{-1}$ along the permanence period. Relative to the average growing stock of $222 \mathrm{~m}^{3} \mathrm{ha}^{-1}$, carbonoriented retention represents only $11 \%$, i.e., a retention that should not be generate dramatic income losses if practiced, and that on the other hand will generate other
Tab. 4 - Species-specific coefficient for carbon accounting in Italian forests (Vitullo et al. 2007).

\begin{tabular}{lccc}
\hline Species & $\boldsymbol{B C E} \boldsymbol{F}$ & $\boldsymbol{\rho}$ & $\boldsymbol{R}$ \\
\hline casa & 1.33 & 0.49 & 0.28 \\
fasy & 1.36 & 0.61 & 0.20 \\
qupe & 1.42 & 0.67 & 0.20 \\
rops & 1.47 & 0.53 & 0.24 \\
wood & 1.44 & 0.52 & 0.42 \\
lade & 1.22 & 0.56 & 0.29 \\
pisy & 1.33 & 0.47 & 0.36 \\
shru & 1.49 & 0.63 & 0.62 \\
piab & 1.29 & 0.38 & 0.29 \\
abal & 1.34 & 0.38 & 0.28 \\
ripa & 1.39 & 0.41 & 0.23 \\
plantations & 1.36 & 0.40 & 0.25 \\
\hline
\end{tabular}

Tab. 5 - Current mean stock, total, and harvestable area for each forest cover type in the study site. (a): Excluding areas subject to wildfire or harvest in the last 15 years, site or fertility limitations, or special protection.

\begin{tabular}{lccccc}
\hline $\begin{array}{l}\text { Forest cover } \\
\text { type }\end{array}$ & $\begin{array}{c}\text { Stock } \\
\left(\mathbf{m}^{3} \mathbf{h a}^{-1}\right)\end{array}$ & $\begin{array}{c}\text { Total area } \\
\text { (ha) }\end{array}$ & $\begin{array}{c}\text { Publicly } \\
\text { owned (ha) }\end{array}$ & $\begin{array}{c}\text { Harvestable }^{(\mathbf{a})} \\
(\mathbf{h a})\end{array}$ & $\begin{array}{c}\text { Accessible } \\
(\text { AWS - ha) }\end{array}$ \\
\hline casa & 205.1 & $3,291.4$ & 196.5 & 178.0 & 81.3 \\
fasy & 238.8 & $3,251.8$ & $2,255.6$ & $2,107.0$ & 765.1 \\
qupe & 159.4 & 725.0 & 210.8 & 210.8 & 107.3 \\
wood & 159.4 & 481.2 & 301.5 & 0 & 0 \\
lade & 251.8 & $1,868.5$ & 946.9 & 944.4 & 381.5 \\
pisy & 275.0 & 932.1 & 456.3 & 72.0 & 26.8 \\
abal & 275.0 & 57.8 & 50.3 & 50.3 & 39.3 \\
ripa & 76.5 & 471.9 & 311.1 & 0 & 0 \\
plantations & 274.8 & 455.4 & 291.4 & 282.0 & 206.0 \\
Total & - & $11,525.1$ & $5,020.2$ & $3,844.4$ & $1,607.3$ \\
\hline
\end{tabular}

Tab. 6 - Total stock, harvest scenarios, avoided harvest (baseline-IFM), and net carbon credits (after discounting harvest and hauling emissions) in $\mathrm{MgCO}_{2}$ e generated in the study area (AWS only) for each forest cover type.

\begin{tabular}{lrrrrr}
\hline $\begin{array}{l}\text { Forest cover } \\
\text { type in AWS }\end{array}$ & $\begin{array}{c}\text { Total stock } \\
\left(\mathbf{m}^{3}\right)\end{array}$ & $\begin{array}{c}\text { Baseline } \\
\text { harvest }\left(\mathbf{m}^{3}\right)\end{array}$ & \multicolumn{1}{c}{$\begin{array}{c}\text { IFM } \\
\left(\mathbf{m}^{3}\right)\end{array}$} & $\begin{array}{r}\text { Baseline - } \\
\text { IFM }\left(\mathbf{m}^{3}\right)\end{array}$ & $\begin{array}{c}\text { Net } \mathrm{CO}_{2} \mathbf{e} \\
(\mathbf{M g})\end{array}$ \\
\hline casa & $20,415.6$ & $13,952.6$ & $11,684.1$ & $2,268.5$ & 3,025 \\
fasy & $182,858.9$ & $95,911.1$ & $67,230.8$ & $28,680.3$ & 48,681 \\
qupe & 452.2 & 408.0 & 340.0 & 68.0 & 4,271 \\
wood & 0.0 & 0.0 & 0.0 & 0.0 & 0 \\
lade & $78,140.3$ & $24,334.5$ & $23,447.4$ & 887.1 & 0 \\
pisy & $7,372.2$ & $2,948.9$ & $2,211.7$ & 737.2 & 980 \\
abal & $10,803.1$ & $4,321.2$ & $3,240.9$ & $1,080.3$ & 1,171 \\
ripa & 0.0 & 0.0 & 0.0 & 0.0 & 0 \\
plantations & $56,437.2$ & $22,621.6$ & $16,980.6$ & $5,641.1$ & 5,886 \\
Total & $356,479.4$ & $164,497.9$ & $125,135.4$ & $39,362.4$ & 64,014 \\
\hline
\end{tabular}

environmental co-benefits (e.g., improved Scots pine forest in central Germany. natural hazard protection and increased More detailed computation can be atbiodiversity habitat) beyond the monetary tained by calibrating and applying individincome from carbon credits. Also, it looks ual-, stand- or landscape-scale simulators of that under such scenarios the unrealized forest dynamics (Chen et al. 2000, Masera timber sales should be at least equally com- et al. 2003, Lasch et al. 2005, Bravo et al. pensated by the carbon credit value over 2008), which can be sensitive to managethe 20-years maintenance time prescribed ment, climate change, and stochastic natuby carbon credit guidelines. In a similar ral disturbances, and are able to take into study based on modelling carbon fluxes, account all aboveground and belowground Lasch et al. (2005) suggested that reducing carbon pools, including trade-offs with carthinning intensity from $80 \%$ to $60 \%$ of basal bon stocked in wood products (Lippke et area could result in a 5 to $20 \%$ increase in al. 2011), ecosystem feedbacks (Noormets aboveground carbon after 50 years in a et al. 2015), and uncertainties, eventually 
Fig. 5 - Relationship between retained canopy cover and percent volume in 12 plots after simulated harvest (filled circles: high intensity, crosses: low intensity, empty circle: validation set). Dashed line: exponential fit. Solid line: 1-to-1 relationship.

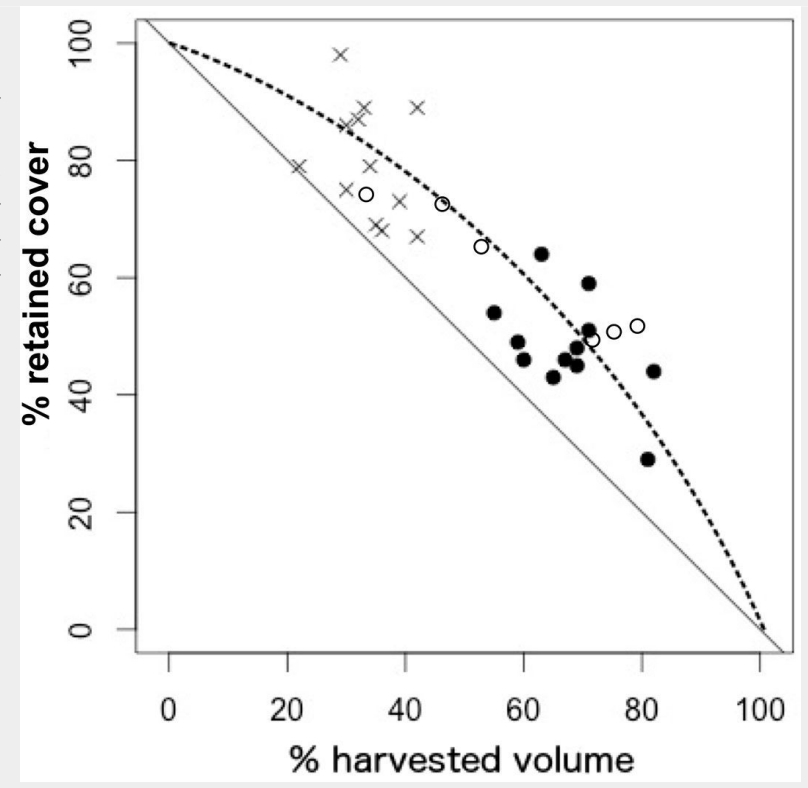

replacing the stock difference approach by a process-based flux computation. In particular, soil carbon typically represents about $50 \%$ of total ecosystem stored carbon (Vacchiano et al. 2015), and its changes may become relevant when more than one rotation, or alternatives such as deforestation or clear-cutting, are included into the baseline or alternative management scenarios (Harmon \& Marks 2002). The most promising approach for operational forest management and planning is represented by stand-scale empirical and semi-empirical simulators, which are still capable of track ing all carbon pools but rely on simple as sumptions and do not require extensive calibration or parameterization by local forest managers (Kurz et al. 2002).

\section{Conclusions}

Retention forestry has a long-standing tradition in Italy, with the main purpose to prevent soil erosion and degradation (Venzi 2008). As a country where harvest is less than $15 \%$ of its annual increment (FAO 2015), forest management regulations must pursue the uncertain trade-off between ensuring soil stability and ecosystem integrity, allowing a certain amount of productive silviculture, and managing forests for natural hazard protection and mitigation of climate change. Specific provisions for other ecosystem services, including carbon sequestration, are still lacking from regulatory and planning documents. The present study demonstrates that the current retention prescriptions in Piemonte are quite modest (Tab. 2): 10\% retained canopy cover in coppices, corresponding to $90 \%$ volume removed, and $50 \%$ retained cover after thinning in high forest and conversion of overmature coppices, corresponding to $60-80 \%$ volume removed in a single entry (Fig. 5). The average volume of living trees in all forests of the region is 151 $\mathrm{m}^{3} \mathrm{ha}^{-1}$ (Gasparini \& Tabacchi 2011), ranging from 100 (oak forests) to $180-200$ (beech, larch, Scots pine, chestnut) to $350-360 \mathrm{~m}^{3}$ $h^{-1}$ (fir and spruce). Therefore, most legally allowed harvest treatments (except group selection) currently produce large timber removals. This leaves room for additional retention, aimed at generating voluntary carbon credits, while still maintaining treatment efficiency and, presumably, economic viability. In the pilot case study, most carbon credits were generated in beech forests, where avoided harvest under IFM relative to the baseline was higher (40\% volume removed, as opposed to $60 \%$ allowed by FMA for conversion of overmature coppices to high forest).

When planning a silvicultural intervention aiming at additional carbon retention, forest managers in Piemonte currently work with two different units of measurements: (i) retained canopy cover, to comply to FMA prescriptions; and (ii) volume removed, to calculate carbon credits relative to the baselines. We demonstrated that the two variables are related by a decreasing exponential function that, albeit heterogeneous, can be applied as a general reference at a regional level. Since the use of a single cover-volume curve may lead to significant over- or underestimation due to the plastic response of tree crowns to local competition, calibration of local and species-specific curves is advisable, especially for light-demanding broadleaves (Pretzsch \& Dieler 2012).

Application of baselines and IFM scenarios to public forests of three municipalities in southern Piemonte, dominated by beech and chestnut coppices, showed potential for IFM to generate voluntary carbon credits. Provided that a local voluntary carbon market is established, the baselines published in the guidelines may help forest managers in evaluating the feasibility and economic return of managing forests for carbon. The forestry sector currently accounts for only $0.3 \%$ of the GDP in Piemonte region (Schulz et al. 2014); espe- cially in areas with poor accessibility and high harvesting costs, even a relatively small income from voluntary carbon credits could make a difference for forest owners. Moreover, managing for carbon might improve the provision of other forest ecosystem services, creating more microhabitats for woodland species (Negro et al. 2015) and enhancing the protective effects of forests against rockfall or snow movements (Vacchiano et al. 2015). The certification of carbon credits could well be extended to privately owned forests, which are the greatest share of chestnut and oak stands; these were left out from this study because no incentive currently exists for active management in (mostly abandoned) private mountain forests, but such limitation could eventually be alleviated by adequate policies. At any rate, the certification of carbon credits ex ante, i.e., before IFM is applied, is considered more reliable in public forests, where compliance to the planned management schedule for the entirety of the permanence period (20 years) is more certain.

The steps adopted in this study (Fig. 4) can be replicated in other mountain regions where there is interest in promoting carbon stocking as an alternative or an addition to production-oriented forest management. Provided that the demand side of the voluntary carbon market can be supported, more and larger-scale studies are needed to demonstrate whether voluntary carbon credits offer a form of payment for ecosystem services that integrates forest owners' income and promotes forest management in the increasingly abandoned and marginalized areas of the southern Alps.

\section{Acknowledgements}

The authors wish to acknowledge Regione Piemonte and IPLA S.p.A for provision of regional forest inventory data, and Marco Allocco, Guido Blanchard, Alberto Dotta, Franco Molteni, Fabio Petrella, and Pier Giorgio Terzuolo for the opportunity to collaborate to the preparation of regional guidelines for carbon credit generations. The authors support the campaign \#ricercaprecaria for the full implementation of the European Charter for Researchers and the acknowledgement of all researchers as workers, and the Change.org petition "Salviamo la ricerca italiana" (http://www.change.org/p/salviamo-la-ricer ca-italiana) for the increase of research funding in Italy to levels requested by the EU Lisbon strategy.

\section{References}

Alberdi I, Michalak R, Fischer C, Gasparini P, Brändli UB, Tomter SM, Kuliesis A, Snorrason A, Redmond J, Hernández L, Lanz A (2016). Towards harmonized assessment of European forest availability for wood supply in Europe. Forest Policy and Economics 30: 20-29. - doi: 10.1016/j.forpol.2016.05.014

Alisciani F, Carbone F, Perugini L (2011). Critical 
issues and challenges in the post-2012 perspective for the possible participation of the forestry sector market for carbon credits. Forest@ 8 (5): 149-161. [in Italian with English summary] - doi: 10.3832/eforo672-008

Bayon R, Hawn A, Hamilton K (2007). Voluntary carbon markets: an international business guide to what they are and how they work. Routledge, London, UK, pp. 184.

Bravo F, Bravo-Oviedo A, Diaz-Balteiro L (2008). Carbon sequestration in Spanish Mediterranean forests under two management alternatives: a modeling approach. European Journal of Forest Research 127 (3): 225-234. - doi: 10.1007/s10342-007-0198-y

Brun F, Mosso A, Blanc S (2014). Analisi delle istanze di taglio presentate in Piemonte nelle ultime stagioni silvane [Analysis of harvest request filed in Piedmont in the recent years]. Dipartimento di Scienze Agrarie, Forestali e Alimentari, Università di Torino, Torino, Italy, pp. 86. [in Italian]

Chen W, Chen JM, Price DT, Cihlar J, Liu J (2000). Carbon offset potentials of four alternative forest management strategies in Canada: a simulation study. Mitigation and Adaptation Strategies for Global Change 5 (2): 143-169. - doi: 10.1023/A:1009671422344

Ciccarese L, Elsasser P, Horattas A, Pettenella D, Valatin G, Weiss G, Ollonqvist P, Slee B (2011). Innovative market opportunities related to carbon sequestration in European forests. In: "Innovation in Forestry - Territorial and Value Chain Relationships" (Weiss G, Pettenella D, Ollonqvist $\mathrm{P}$, Slee B eds). CABI, Wallingford, UK, pp. 131-153. [online] URL: http://books. google.com/books?id=I5P7SipWge8C

Eriksson E, Gillespie AR, Gustavsson L, Langvall O, Olsson M, Sathre R, Stendahl J (2007). Integrated carbon analysis of forest management practices and wood substitution. Canadian Journal of Forest Research 37 (3): 671-681. - doi: 10.1139/Xo6-257

FAO (2015). Italy - Global forest resources assessment 2015. Country report, web site. [online] URL: http://www.fao.org/3/a-az245e.pdf

Garlato A, Obber S, Vinci I, Sartori G, Manni G (2009). Stock attuale di carbonio organico nei suoli di montagna del Veneto [The actual stock of organic carbon in the mountain soil profiles of Veneto Region]. Studi Trentini di Scienze Naturali 85: 69-81. [in Italian]

Gasparini P, Tabacchi G (2011). L'Inventario Nazionale delle Foreste e dei serbatoi forestali di Carbonio INFC 2005. Secondo inventario forestale nazionale italiano. Metodi e risultati [National inventory of forests and forest carbon sinks INFC 2005. Second Italian national forest inventory. Methods and results]. Ministero delle Politiche Agricole, Alimentari e Forestali, Corpo Forestale dello Stato, Consiglio per la Ricerca e la Sperimentazione in Agricoltura, Unità di ricerca per il Monitoraggio e la Pianificazione Forestale, Edagricole, Bologna, Italy, pp. 653. [in Italian]

Gottero F, Ebone A, Terzuolo P, Camerano P (2007). I boschi del Piemonte: conoscenza e indirizzi gestionali [Forests in Piedmont: knowledge base and management options]. Regione Piemonte e Blu Edizioni, Torino, Italy, pp. 240. [in Italian]
Green JF (2013). Order out of chaos: public and private rules for managing carbon. Global Environmental Politics 13 (2): 1-25. - doi: 10.1162/ GLEP_a_00164

Hamrick K, Goldstein A (2016). Raising ambition: state of the voluntary carbon markets 2016. Ecosystem Marketplace Forest Trends, Washington, DC, USA, pp. 50.

Harmon ME, Marks B (2002). Effects of silvicultural practices on carbon stores in Douglas-fir western hemlock forests in the Pacific Northwest, USA: results from a simulation model. Canadian Journal of Forest Research 32 (5): 863-877. - doi: 10.1139/x01-216

Jandl R, Bauhus J, Bolte A, Schindlbacher A, Schüler S (2015). Effect of climate-adapted forest management on carbon pools and greenhouse gas emissions. Current Forestry Reports 1 (1): 1-7. - doi: 10.1007/s40725-015-0006-8 Kurz WA, Apps M, Banfield E, Stinson G (2002). Forest carbon accounting at the operational scale. The Forestry Chronicle 78 (5): 672-679. doi: $10.5558 /$ tfc78672-5

Lasch P, Badeck FW, Suckow F, Lindner M, Mohr $P$ (2005). Model-based analysis of management alternatives at stand and regional level in Brandenburg (Germany). Forest Ecology and Management 207 (1): 59-74. - doi: 10.1016/j.foreco.20 04.10 .034

Lippke B, Oneil E, Harrison R, Skog K, Gustavsson L, Sathre R (2011). Life cycle impacts of forest management and wood utilization on carbon mitigation: knowns and unknowns. Carbon Management 2 (3): 303-333. - doi: $10.4155 / \mathrm{cmt}$. 11.24

Low KF, Lin J (2015). Carbon credits as EU like it: property, immunity, tragi $\mathrm{CO}_{2}$ medy? Journal of Environmental Law 27: 377-404. - doi: 10.1093/ jel/eqvoro

Lowman M, Rinker HB (2004). Forest canopies. Elsevier Academic Press, Burlington, MS, USA, pp. 517. [online] URL: http://books.google. com/books?id=T9qY2AxnUowC

Masera OR, Garza-Caligaris JF, Kanninen M, Karjalainen T, Liski J, Nabuurs GJ, Pussinen A, De Jong BH, Mohren GM (2003). Modeling carbon sequestration in afforestation, agroforestry and forest management projects: the $\mathrm{CO}_{2} \mathrm{FIX} \mathrm{V}$. 2 approach. Ecological Modelling 164 (2): 177199. - doi: 10.1016/S0304-3800(02)00419-2

McFarland BJ (2012). Carbon reduction projects and the concept of additionality. Sustainable Development Law and Policy 11: 15-18.

Mitchell JE, Popovich SJ (1997). Effectiveness of basal area for estimating canopy cover of ponderosa pine. Forest Ecology and Management 95: 5-51. - doi: 10.1016/S0378-1127(97)00002-9 Murray BC, Olander LP (2008). Addressing impermanence risk and liability in agriculture, land use change, and forest carbon projects. Nicholas Institute for Environmental Policy Solutions, Duke University, Durham NC, USA, pp. 13.

Nabuurs G-J, Delacote P, Ellison D, Hanewinkel $M$, Lindner $M$, Nesbit $M$, Ollikainen $M$, Savaresi A (2015). A new role for forests and the forest sector in the EU post-2020 climate targets. From Science to Policy 2. European Forest Institute, Joensuu, Finland, pp. 32. [online] URL: http://library.wur.nl/WebQuery/wurpubs/49508
Negro M, Vacchiano G, Berretti R, Chamberlain DE, Palestrini C, Motta R, Rolando A (2015). Effects of forest management on ground beetle diversity in alpine beech (Fagus sylvatica L.) stands. Forest Ecology and Management 328: 300-309. - doi: 10.1016/j.foreco.2014.05.049 Negro M, Caprio E, Leo K, Maritano U, Roggero A, Vacchiano G, Palestrini C, Rolando A (2017). The effect of forest management on endangered insects assessed by radio-tracking: the case for the ground beetle Carabus olympiae in beech Fagus sylvatica stands. Forest Ecology and Management 406: 125-137. - doi: 10.1016/j. foreco.2017.09.065

Noormets A, Epron D, Domec JC, McNulty SG, Fox T, Sun G, King JS (2015). Effects of forest management on productivity and carbon sequestration: a review and hypothesis. Forest Ecology and Management 355: 124-140. - doi: 10.1016/j.foreco.2015.05.019

Nosenzo A (2005). Sistemi di tariffe per la cubatura delle principali conifere della Regione Valle d'Aosta [Volume table systems for the main softwood species in Valle d'Aosta region]. In: "Atti del IV Congresso Nazionale della Società Italiana di Selvicoltura e Ecologia Forestale" (Caivano F, Girardi T, Pierangeli D, Borghetti M eds). Potenza (Italy) 7-10 Oct 2003. Università degli Studi della Basilicata, Potenza, Italy, pp. 209-213. [in Italian]

Nosenzo A (2008). Double-entry volume table for beech coppices in Piedmont. Forest@ 5: 227-232. [in Italian with English summary] - doi: 10.3832/eforo539-0050227

Nucleo Monitoraggio Carbonio (2014). Codice forestale del Carbonio [Code of forest carbon]. Rivista Sherwood, Compagnia delle Foreste, Arezzo, Italy, pp. 23. [in Italian] [online] URL: http://www.rivistasherwood.it/serviziecosistem ici/filesvari/notizie/2014/Codice_Forestale_del_ Carbonio_1.0-Ottobre_2014.pdf

Olander J, Ebeling J (2011). Building forest carbon projects: step-by-step overview and guide. Forest Trends, Washington, DC, USA, pp. 66.

Pan Y, Birdsey RA, Fang J, Houghton R, Kauppi PE, Kurz WA, Phillips OL, Shvidenko A, Lewis SL, Canadell JG, Ciais P (2011). A large and persistent carbon sink in the world's forests. Science 333 (6045): 988-993. - doi: 10.1126/scien ce.1201609

Penman J, Gytarsky M, Hiraishi T, Krug T, Kruger D, Pipatti R, Buendia L, Miwa K, Ngara T, Tanabe K, Wagner F (2003). Good practice guidance for land use, land-use change and forestry. IPCC Technical Support Unit, Kanagawa, Japan, pp. 583. [online] URL: http:// www.cabdirect.org/cabdirect/abstract/2008316 2304

Pretzsch H, Dieler J (2012). Evidence of variant intra- and interspecific scaling of tree crown structure and relevance for allometric theory. Oecologia 169: 637-649. - doi: 10.1007/s00442011-2240-5

R Core Team (2016). R: a language and environment for statistical computing. R Foundation for Statistical Computing, Vienna, Austria. [online] URL: http://www.r-project.org

Regione Piemonte (2011). Regolamento forestale di attuazione dell'articolo 13 della legge regionale 10 febbraio 2009 , n. 4 [Forest management act after article 13 of regional law no. 
4, $10^{\text {th }}$ February 2009]. DPGR 8/R/2011, Regione Piemonte, Torino, Italy, pp. 62. [in Italian] [online] URL: http://www.regione.piemonte.it/ foreste/images/files/pian_gest/dwd/nuova_leg ge/testointegrato2015.pdf

Regione Piemonte (2014). Misure di conservazione per la tutela dei siti della Rete Natura 2000 del Piemonte [Measures for conservation in Natura 2000 sites in Piedmont]. DGR 547409/2014, Regione Piemonte, Torino, Italy, pp. 88. [in Italian] [online] URL: http://www. regione.piemonte.it/parchi/cms/dwd/DGR_n54 _7409del7_4_2014.pdf

Regione Piemonte (2016a). Sistema informativo territoriale ambientale diffuso. Aree Protette e Rete Natura 2000 - Mapservice [Land and environment web information system. Protected areas and Natura 2000 sites]. Web site. [in Italian] [online] URL: http://www.sistemapiemon te.it $/ \mathrm{sitad} / \mathrm{metadata}$ 1.do?idEntita $=10002414$

Regione Piemonte (2016b). Sistema informativo territoriale ambientale diffuso. Incendi boschivi [Land and environment web information system. Forest fires]. Web site. [in Italian] [online] URL: http://www.sistemapiemonte.it/sitad/me tadata_1.do?idEntita $=10000613$

Regione Piemonte (2016c). Sistema informativo territoriale ambientale diffuso. Piani Forestali Territoriali. [Land and environment web information system. Territorial forest management plans]. Web site. [in Italian] [online] URL: http://www.sistemapiemonte.it/sitad/metadata 1.do?idEntita $=10002910$

Regione Piemonte (2016d). Sistema informativo territoriale ambientale diffuso. Viabilità di interesse silvo-pastorale esistente. [Land and envi- ronment web information system. Silvo-pastoral road network]. Web site. [in Italian] [online] URL: http://www.sistemapiemonte.it/sitad /metadata_1.do?idEntita $=10002912$

Regione Piemonte (2017). Approvazione del Piano Forestale Regionale 2017-2027. [Regional forest plan 2017-2027]. DGR 8-4545/2017, Giunta Regionale Piemonte, Torino, Italy, pp. 6. [in Italian] [online] URL: http://www.regione.piemon te.it/foreste/images/files/pian_gest/pfr/D.G.R. 8-4585.pdf

Schulz T, Krumm F, Bücking W, Frank G, Kraus D, Lier M, Lovri M, Van Der Maaten-Theunissen M, Paillet Y, Parviainen J, Vacchiano G (2014). Comparison of integrative nature conservation in forest policy in Europe: a qualitative pilot study of institutional determinants. Biodiversity and Conservation 23 (14): 3425-3450. - doi: $10.1007 \mid$ S10531-014-0817-0

Swanson ME (2009). Modeling the effects of alternative management strategies on forest carbon in the Nothofagus forests of Tierra del Fuego, Chile. Forest Ecology and Management 257 (8): 1740-1750. - doi: 10.1016/j.foreco.2009. 01.045

Tabacchi G, Di Cosmo L, Gasparini P, Morelli S (2012). Stima del volume e della fitomassa delle principali specie forestali italiane. Equazioni di previsione, tavole del volume e tavole della fitomassa arborea epigea. [Assessment of volume and biomass of the main tree species in Italy. Model equations, volume tables, and aboveground biomass tables]. Consiglio per la Ricerca e la sperimentazione in Agricoltura, Unità di Ricerca per il Monitoraggio e la Pianificazione Forestale, Trento, Italy, pp. 411. [in Ital- ian]

Tomao A, Carbone F, Marchetti M, Santopuoli G, Angelaccio C, Agrimi M (2013). Forest, trees, externalities and ecosystem services. Italian Journal of Forest and Mountain Environments 68 (2): 57-73. - doi: 10.4129/IFM.2013.2.01 Vacchiano G, Magnani F, Collalti A (2012). Modeling Italian forests: state of the art and future challenges. iForest 5: 113-120. - doi: 10.3832/ifor 0614-005

Vacchiano G, Perseghin G, Maggioni M, Motta R (2015). Effect of avalanche frequency on forest ecosystem services in a spruce-fir mountain forest. Cold Regions Science and Technology 115: 9-21. - doi: 10.1016/j.coldregions.2015.03.004 Van Kooten GC, Bogle TN, De Vries FP (2015). Forest carbon offsets revisited: shedding light on Darkwoods. Forest Science 61: 370-380. doi: 10.5849/forsci.13-183

Venzi L (2008). Outlines of forest policy in Italy: past experiences and recent developments. In: "The multifunctional role of forests - Policies, methods and case-studies" (Cesaro L, Gatto P, Pettenella D eds). European Forest Institute, Joensuu, Finland, pp. 39-46. [online] URL: http://www.efi.int/files/attachments/publicatio ns/efi_proc55_net.pdf\#page $=41$

Vitullo M, De Lauretis R, Federici S (2007). La contabilità del carbonio contenuto nelle foreste italiane [Accounting for carbon in Italian forests]. Silvae 3: 91-104. [in Italian]

Weng CK, Boehmer K (2006). Launching of ISO 14064 for greenhouse gas accounting and verification. ISO Management Systems 15: 14-16. [online] URL: http://s3.amazonaws.com/acade mia.edu.documents/31113306/ 